\title{
GAYA KEPEMIMPINAN MENENTUKAN KEPUASAN KERJA PT. KERETA API INDONESIA DAOP IX JEMBER
}

\author{
SOVIA ANGGRAINI SETIONO \\ Program Studi Ilmu Administrasi Bisnis, \\ Sekolah Tinggi Ilmu Administrasi Pembangunan Jember \\ Email: Sovia@gmail.com
}

\begin{abstract}
ABSTRAK
Penelitian ini dilakukan untuk pengaruh secara simultan dapat dilihat dari hasil analisis uji $F$ yang dilakukan yaitu menghasilkan nilai $F_{\text {hitung }}$ lebih besar dari $F_{\text {tabel }}(60,789>3,24)$ maka Ho ditolak, artinya bahwa aspek-aspek pembentuk gaya kepemimpinan secara simultan mempunyai pengaruh signifikan terhadap kepuasan kerja pegawai PT. Kereta Api Indonesia DAOP IX Jember. Sedangkan dari hasil analisis uji t menunjukkan bahwa untuk variabel gaya kepemimpinan berorientasi tugas lebih besardari $t_{\text {tabel }}$ $(5,155>1,68)$ dan untuk variabel gaya kepemimpinan berorientasi hubungan memiliki nilai $t_{\text {hitung }}$ lebih besar dari $t_{\text {tabel }}(3,299>1,68)$. Berdasarkan hasil analisis koefisien determinasi berganda ( $R$ Square) diperoleh nilai $\boldsymbol{R}$ Square sebesar $\mathbf{0 , 7 6 2}$. Hal itu mempunyai arti bahwa sumbangan yang diberikan aspek-aspek pembentuk gaya kepemimpinan yang terdiri dari gaya kepemimpinan berorientasi tugas dan gaya kepemimpinan berorientasi hubungan secara bersama-sama terhadap kepuasan kerja pegawai PT. Kereta Api Indonesia DAOP IX Jember adalah sebesar 0,762 atau sebesar $76,2 \%$ dan sisanya sebesar $23,8 \%$ dipengaruhi faktor-faktor lain diluar variabel dalam penelitian ini. Sedangkan aspek pembentuk gaya kepemimpinan yang mempunyai pengaruh terbesar terhadap kepuasan kerja pegawai PT. Kereta Api Indonesia DAOP IX Jember adalah variabel gaya kepemimpinan berorientasi tugas. Hal ini dapat terlihat dari hasil analisis koefisien determinasi secara parsial untuk variabel gaya kepemimpinan berorientasi tugas adalah sebesar 0,641 atau sebesar $64,1 \%$.
\end{abstract}

Kata Kunci : gaya kepemimpinan berorientasi tugas, gaya kepemimpinana berorientasi hubungan dan kepuasan kerja pegawai 


\section{PENDAHULUAN}

Setiap perusahaan baik milik pemerintah maupun milik swasta dalam melakukan kegiatannya tidak lepas dari campur tangan sumber daya manusia dalam perusahaan. Sumber daya manusia didalam perusahaan yaitu pegawai memiliki peran penting untuk kegiatan pengembangan dan kemajuan perusahaan, termasuk bidang usaha jasa seperti jasa pelayanan transportasi. Pegawai dalam perusahaan berfungsi sebagai pelaksana pekerjaan yang menjadi tugas pokok organisasi. Nawawi, 2000:15 menyatakan bahwa :

"Pegawai merupakan orang yang bekerja dalam lingkungan organisasi perusahaan yang mencakup manajer dan pelaksana. Dibutuhkan pegawai yang berkualitas guna mencapai tujuan perusahaan. Tujuan perusahaan yang dapat tercapai dengan baik mencerminkan kepuasan kerja dalam diri pegawai."

Pegawai yang bekerja dapat dikatakan bahwa hasrat untuk mencari kepuasan pribadi untuk melakukan sesuatu yang berguna, sangat penting dimiliki oleh manusia, sebab manusia akan menghabiskan sebagian besar waktunya dalam aktifitas kerja. Handoko, 2000:198 menyatakan bahwa :

"Bawahan yang tidak memperoleh kepuasan kerja tidak akan pernah mencapai kematangan psikologis dan pada gilirannya akan menjadi frustasi. Bawahan yang sering melamun, mempunyai semangat kerja yang rendah, cepat lelah dan bosan, emosi yang tidak stabil, sering absen dan melakukan kesibukan yang tidak ada hubungannya dengan pekerjaan yang harus dilakukan. Sedangkan bawahan yang mendapatkan kepuasan kerja biasanya mempunyai catatan kehadiran dan perputaran yang lebih baik dan (kadang-kadang) berprestasi lebih baik dari pada bawahan yang tidak mempunyai kepuasan kerja.

Kepuasan kerja adalah sikap seseorang terhadap pekerjaan mereka. Sikap itu berasal dari persepsi mereka tentang pekerjaannya. Kepuasan kerja kerkaitan dengan sikap yang mana kepuasan kerja mencakup berbagai hal seperti kondisi emosi dan kecenderungan perilaku seseorang. Kepuasan kerja mencerminkan perasaan pegawai terhadap pekerjaannya. Hal ini terlihat pada sikap positif pegawai terhadap pekerjaan dan segala sesuatu yang dihadapi di lingkungan kerjanya. Kepuasan kerja apat dikatakan sebagai keadaan emosional yang menyenangkan atau tidak menyenangkan dimana para pegawai memandang pekerjaannya.

Salah satu transportasi massal yang saat ini ada adalah kereta api. Kereta api memiliki berbagai keunggulan dibandingkan dengan 
moda transportasi lain, yaitu sebagai angkutan yang hemat energi, hemat lahan, bersahabat dengan lingkungan, memiliki tingkat keselamatan tinggi, mampu mengangkut dalam jumlah besar, dan dapat langsung ke pusat kota (www.keretaapi.co.id). Setiap perusahaan dan semua elemenelemen yang berada dalam perusahaan tersebut harus berupaya meningkatkan mutu pelayanan secara berkesinambungan, agar dapat mempertahankan eksistensinya. Hal ini dapat terlaksana oleh perusahaan sehingga tidak tertinggal oleh perusahaan yang lain.

Tingkat kepuasan kerja pegawai merupakan suatu hal yang bersifat individual, sedangkan dalam suatu perusahaan terdapat pegawai yang memiliki berbagai macam sikap, perilaku yang berbeda-beda, sehingga tingkat kepuasan kerja pegawai yang satu dengan yang lain tidaklah sama, sebab apabila seorang pegawai merasa puas dengan pekerjaannya, belum tentu pegawai yang lainnya merasakan hal yang sama. Berdasarkan kondisi dalam perusahaan yang berbeda diperlukan gaya kepemimpinan yang tepat untuk dapat mempengaruhi pegawai agar dapat melalukan pekerjaan dengan baik, sehingga tujuan perusahaan dapat tercapai.

Peranan seorang pemimpin dalam suatu organisasi sangatlah penting, karena keberhasilan maupun kegagalan organisasi sangatlah bergantung kepada pemimpin. Hal ini diungkapkan oleh Miftah Thoha (2003:34) :

"Suatu organisasi akan berhasil atau gagal sebagian besar ditentukan oleh pemimpin. Pemimpinlah yang bertanggung jawab atas kegagalan suatu pekerjaan. Dengan demikian apakah kegiatan-kegiatan yang ada dalam organisasi dapat berjalan dengan lancar atau malah sebaliknya, semua ini tergantung bagaiman cara pemimpin dalam mengarahkan bawahannya".

Seorang pemimpin dengan gaya kepemimpinan yang disukai oleh bawahannya dapat digunakan untuk mempengaruhi bawahan dalam berbagai hal, baik di dalam pekerjaan maupun di luar pekerjaan. Sedangkan kepemimpinan itu sendiri menurut Stogdill (dalam Siswanto, 1990:176) adalah, "suatu kemampuan untuk mempengaruhi orang lain atau bawahan agar mau melakukan perintah dalam rangka mencapai tujuan organisasi".

Gaya kepemimpinan dalam perusahaan yang ditampilkan seorang pemimpin dapat mempengaruhi kepuasan kerja pegawai. Gaya kepemimpinan yang sesuai dan dapat diterima pegawai akan berpengaruh positif terhadap kepuasan kerja pegawai. Kepuasan kerja merupakan salah satu faktor pemicu meningkatnya loyalitas dan produktifitas pegawai dalam suatu instansi. Kepuasan kerja merupakan sikap positif para pegawai yang 
mampu mendorong pegawai dapat bekerja lebih baik.

Kepuasan kerja pegawai PT. Kereta Api Indonesia DAOP IX Jember perlu mendapatkan perhatian dan kajian lebih lanjut dalam kaitannya dengan gaya kepemimpinan. Dari kajian tersebut diharapkan PT. Kereta Api Indonesia DAOP IX Jember dapat merumuskan strategi gaya kepemimpinan yang diterapkan untuk meningkatkan kepuasan kerja pegawainya sehingga berpengaruh dalam peningkatan produktivitas kerja dan pelayanannya.

Berdasarkan uraian tersebut di atas, maka penulis menentukan judul "Gaya Kepemimpinan Menetukan Kepuasan Kerja Pegawai PT. Kereta Api Indonesia DAOP IX Jember"

\section{TINJAUAN PUSTAKA}

\section{a. Pengertian Kepemimpinan}

Kepemimpinan adalah kualitas kemampuan pribadi yang dimiliki seseorang untuk menggerakkan bawahan untuk mencapai tujuan organisasi. Menurut Siagian (2003:2) keberhasilan suatu organisasi baik secara keseluruhan maupun kelompok dalam suatu organisasi tertentu sangat tergantung pada kualitas kepemimpinan organisasi tersebut. Pemimpin adalah seseorang yang memiliki kelebihan berupa kepemimpinan. Sedangkan kepemimpinan dapat diartikan sebagai kemampuan untuk mendorong sejumlah orang agar bekerja sama dalam melaksanakan kegiatan yang terarah pada tujuan yang sama.

Menurut Stogdill (dalam Yukl, 1998:2), kepemimpinan didefinisikan dalam kaitan dengan ciri individual, perilaku, pengaruh terhadap orang lain, pola interaksi, hubungan peran, tempat pada suatu posisi administrasi serta persepsi orang lain.

Winardi

(1996:47)

mengemukakan bahwa kepemimpinan merupakan suatu kemampuan yang melekat pada seseorang yang memimpin, tergantung dari macam-macam faktor, baik intern maupun ekstern. Adakalanya pemimpin menonjol pada satu permasalahan namun memudar pada permasalahn yang lain.

Selain melakukan interaksi, pemimpin harus dapat melakukan hal-hal sebagai berikut :

1. memberikan inspirasi kepada bawahan,

2. melaksanakan pekerjaan dan mengembangkan pekerjaan,

3. menunjukkan pada bawahan cara melaksanakan pekerjaan,

4. menerima tanggung jawab,

5. menyelesaikan persoalan kerugian yang timbul dalam tiap bagian perusahaan.

\section{b. Fungsi Kepemimpinan}

Menurut Stoner dan Freeman (1994:57), supaya bisa beroperasi secara efektif, sebuah kelompok membutuhkan seseorang untuk menjalankan dua fungsi utama: 
fungsi "yang bertalian dengan tugas" atau fungsi pemecahan masalah, dan fungsi "pembinaan kelompok" atau fungsi sosial, seperti menjadi penengah dalam perselisihan dan menjamin bahwa para individu merasa dihargai oleh kelompok.

Sondang Siagian menyatakan bahwa ada 5 fungsi dari kepemimpinan yang hakiki (Rois dan Siti, 2003:113), yaitu:

1. Fungsi penentu arah

Tujuan yang ada di setiap organisasi dapat dicapai melalui kerja sama yang dipimpin oleh seorang pemimpin. Keterbatasan sumber daya organisasi mengharuskan pemimpin untuk mengelola dengan efektif, dengan kata lain arah yang hendak dicapai oleh organisasi menuju tujuannya harus sedemikian rupa sehingga mengoptimalkan pemanfaatan dari segala sarana dan prasarana yang ada. Arah yang dimaksud tertuang dalam strategi dan taktik yang disusun oleh pimpinan dalam organisasi.

2. Fungsi sebagai juru bicara

Fungsi pemimpin sebagai juru bicara mengharuskan seorang pemimpin untuk berperan sebagai penghubung antara organisasi dengan pihak-pihak luar yang berkepentingan seperti pemilik saham, pemasok, penyalur, lembaga keuangan, dan instansi pemerintah yang terkait.

3. Fungsi sebagai komunikator
Fungsi pemimpin sebagai komunikator lebih ditekankan pada kemampuannya untuk mengkomunikasikan sasaransasaran, strategi, dan tindakan yang harus dilakukan oleh bawahan.

4. Fungsi sebagai mediator

Konflik-konflik yang terjadi atau adanya perbedaan-perbedaan kepentingan dalam organisasi menuntut kehadiran seorang pemimpin dalam menyelesaikan permasalahan yang ada. Jadi kemampuan menjalankan fungsi kepemimpinan selaku mediator yang rasional, objektif dan netral merupakan salah satu indikator efektifitas kepemimpinan seseorang.

5. Fungsi sebagai integrator

Adanya pembagian tugas, sistem alokasi sumber daya, dana dan tenaga, serta spesialisasi pengetahuan dan keterampilan dapat menimbulkan sikap, perilaku dan tindakan berkotakkotak. Sehingga diperlukan integrator terutama pada hirarki puncak organisasi. Integrator itu adalah pimpinan, semakin tinggi kedudukan seseorang dalam hirarki kepemimpinan dalam organisasi, semakin penting pula makna peranan tersebut.

\section{c. Gaya Kepemimpinan}

Menurut Siagian (2003:297) gaya kepemimpinan adalah keseluruhan tabiat atau sifat seseorang yang terefleksi dalam 
ucapan dan tindakan sebagai anggota organisasi.

Gaya kepemimpinan merupakan pola perilaku yang konsisten yang diterapkan dalam bekerja dengan dan melalui orang lain seperti yang dipersepsikan seseorang (Hersey dan Blanchard, 1995:238). Gaya kepemimpinan adalah tindakan khusus seorang pemimpin yang terlibat dalam rangkaian usaha menggerakkan dan mengkoordinasikan pekerja anggota kelompoknya. Peran strategis gaya kepemimpinan dalam suatu organisasi dapat mewujudkan kepuasan kerja.

Teori gaya kepemimpinan yang paling menyeluruh dan ditiru dihasilkan dari riset yang dimulai pada Universitas Negeri Ohio. Riset tersebut menyempitkan daftar (dimensi) menjadi dua kategori yang secara hakiki menjelaskan kebanyakan perilaku kepemimpinan yang digambarkan oleh bawahan. Mereka menyebut kedua dimensi ini sebagai struktur prakarsa atau initiating structure dan pertimbangan atau consideration (Robbins, 2002:5).

Telaah Universitas Michigan juga sampai pada dua dimensi perilaku kepemimpinan yang mereka sebut berorientasi karyawan dan berorientasi produksi (Robbins, 2002:6).

\section{d. Gaya Kepemimpinan Ber- orientasi Tugas}

Gaya kepemimpinan berorientasi tugas menurut Hersey dan Blanchard (1995:113) adalah tingkatan dimana seorang pemimpin terlibat dalam peran pendefinisian apa-apa yang harus dikerjakan, bagaimana, dimana, kapan. Kemudian menentukan ketepatan waktu dan mengontrol. Lebih lanjut Hersey dan Blanchard (1995:105) menyatakan bahwa "struktur inisiasi (berorientasi tugas) mengacu pada perilaku pemimpin dalam menggambarkan hubungan antara dirinya sendiri dengan anggota kelompok kerja dan dalam upaya membentuk pola organisasi, saluran komunikasi, dan metode atau prosedur yang ditetapkan dengan baik".

Mengenai gaya kepemimpinan berorientasi tugas, Robbins (2002:7) berpendapat bahwa berorientasi produksi (berorientasi tugas) ialah kecenderungan seorang pemimpin yang menekankan aspek teknis atau tugas dari pekerjaan dan perhatian utama mereka adalah pada penyelesaian tugas kelompok dan anggota kelompok adalah suatu alat untuk tujuan akhir.

\section{e. Gaya Kepemimpinan Ber- orientasi Hubungan}

Mengenai gaya kepemimpinan berorientasi hubungan, Hersey dan Blanchard mendefinisikan sebagai suatu tingkatan di mana pemimpin terlibat dalam komunikasi dua arah, mendengarkan, memberi fasilitas dan 
memberi dukungan, berkomunikasi, interaksi, pemberian fasilitas, mendengarkan secara aktif dan memberikan umpan balik.

Sedangkan menurut Robbins (2002:7), bahwa employee-oriented (berorientasi hubungan) merupakan suatu gaya kepemimpinan yang menekankan hubungan antar pribadi dan pemimpin yang berminat secara pribadi pada kebutuhan bawahan serta menerima baik perbedaan di antara anggota-anggota. Hampir sama dengan pendapat Hersey dan Blanchard (1995:105) bahwa konsiderasi (beorientasi hubungan) mengacu pada perilaku yang menunjukkan persahabatan, kepercayaan, timbal balik, rasa hormat dan kehangatan di dalam hubungan antara pemimpin dengan anggota staff.

\section{f. Definisi Kepuasan Kerja}

Teori kepuasan memusatkan perhatian pada faktor-faktor di dalam individu yang mendorong, mengarahkan, dan mempertahankan, dan menghentikan perilaku (Gibson et al. 1996:186). Mereka mencoba untuk menentukan kebutuhankebutuhan spesifik yang memotivasi orang. Teori kepuasan memusatkan diri pada kebutuhan individu di dalam menjelaskan kepuasan kerja, perilaku kerja dan sistem imbalan. Teori tersebut menyatakan bahwa efisiensi kebutuhan di dalam diri individu memicu suatu respon perilaku.
Menurut Handoko (2000:282), kepuasan kerja adalah keadaan emosional yang menyenangkan atau tidak menyenangkan dengan mana karyawan memandang pekerjaan mereka. Menurut Robbins (2002:180), kepuasan kerja adalah sikap umum dari para karyawan atas pekerjaannya. Umar (2000:36) berpendapat kepuasan kerja merupakan penilaian atau cerminan dari perasaan pekerja terhadap pekerjaannya. Sedangkan menurut Siagian (2002:295), kepuasan kerja merupakan suatu cara pandang seseorang baik bersifat positif maupun bersifat negatif tentang pekerjaan.

Dari ketiga pendapat tersebut dapat disimpulkan bahwa kepuasan kerja adalah suatu respon yang bisa menyenangkan atau tidak menyenangkan dari hasil atau ganjaran yang diterima karyawan dari pekerjaannya.

\section{g. Teori Kepuasan Kerja}

Siswanto

(1990:87)

berpendapat bahwa terdapat teori kepuasan hierarki kebutuhan Maslow yang menerangkan bahwa teori ini memandang bahwa manusia mempunyai kebutuhan yang bertingkat-tingkat dari yang paling sederhana hingga yan gpaling tinggi berdasarkan kadar kepentingannya.

Maslow membagi kebutuhan manusia atas, (Gibson et al. 1996:189): 
1. Fisiologis: makanan, minuman, tempat tinggal, dan sembuh dari rasa sakit.

2. Keamanan dan keselamatan: kebutuhan untuk kemerdekaan dari ancaman, yaitu keamanan dari kejadian atau lingkungan yang mengancam.

3. Rasa memiliki, sosial dan kasih sayang: kebutuhan atas persahabatan, berkelompok, interaksi dankasih sayang.

4. Penghargaan (esteem): kebutuhan atas harga diri (self-esteem) dan penghargaan dari pihak lain.

5. Aktualisasi diri: kebutuhan untuk memenuhi diri seseorang melalui memaksimumkan penggunaan kemampuan, keahlian, dan prestasi.

Lebih lanjut menurut Maslow kebutuhan karyawan sebagai manusia berdasarkan hasil penelitian selama ini dapat dikategorikan sebagai berikut:

a. Sistem reward

1. pendapatan mencukupi atau tidak

2. kesesuaian pendapatan dengan pekerjaan

3. keadilan dalam promosi

4. adanya peningkatan karir

5. adanya penghargaan

6. adanya pengakuan

b. Pekerjaan itu sendiri

1. pekerjaan sesuai dengan keinginan

2. pekerjaan sesuai kemampuan
3. melaksanakan pekerjaan sesuai dengan yang diharapkan

4. prestasi yang didapat selama ini

5. melakukan pekerjaan sesuai dengan prosedur

6. perkembangan dalam pekerjaan

c. Keadaan kerja yangmendukung

1. lingkungan kerja

2. fasilitas perusahaan

3. peralatan kerja

4. keamanan dan keselamatan kerja

5. kebersihan dan kerapian

6. kenyamanan dan ketenangan

d. Rekan sekerja yang mendukung,

1. rekan membantu pekerjaan

2. rekan menjadi sahabat

3. rekan banyak bicara

4. pimpinan mendukung

Untuk mengetahui faktor pengaruh kepuasan kerja, dapat digunakan Job Descriptive Indeks (JDI), yaitu (Luthans, dalam Umar, 2000:36): (1) pembayaran, pekerjaan, (3) promosi pekerjaan, (4) kepenyeliaan/supervisi, (5) hubungan bawahan dengan atasan.

Hezberg (dalam Manullang, 1994:151) berpendapat bahwa seseorang dalam melaksanakan pekerjaan dipengaruhi dua faktor utama yang merupakan kebutuhan, yaitu:

1. faktor motivasional, yang meliputi pekerjaan seseorang, keberhasilan yang diraih, kesempatan berkembang, 
kemajuan dalam karir, pengakuan orang lain,

2. faktor pemeliharaan, terdiri dari gaji, kebijaksanaan dalam perusahaan, kondisi kerja, kualitas kepenyeliaan dan hubungan pribadi pegawai dengan atasan dan rekan kerja.

h. Indikasi Rendahnya Kepuasan Kerja

Ada empat respon yang didefinisikan oleh Robbins (1996:184) yaitu:

1. Eksit: perilaku yang diarahkan ke arah meninggalkan organisasi. Mencakup pencarian suatu posisi baru maupun meminta berhenti.

2. Suara (voice): dengan aktif dan kronstruktif mencoba memperbaiki kondisi. Mencakup saran perbaikan, membahas problem-problem dengan atasan, dan beberapa bentuk kegiatan serikat buruh.

3. Kesetiaan (loyalty): pasif tetapi optimis menunggu membaiknya kondisi. Mencakup berbicara membela organisasi menghadapi kritik luar dan mempercayai organisasi dan manajemennya untuk melakukan hal yang tepat.

4. Pengabaian (neglect): secara pasif membiarkan kondisi memburuk, termasuk kemangkiran atau datang terlambat secara kronis, upaya yang dikurangi, dan tingkat kekeliruan yang meningkat.

Menurut Umar (2000:182), indikasi rendahnya kepuasan kerja dapat diketahui dari menurunnya produktivitas kerja, tingkat absensi tinggi, labour turn over tinggi, tingkat kesalahan yang tinggi, pemogokan dan tuntutan yang sering terjadi. Ketidakpuasan akan menimbulkan sikap kurang senang dan tidak nyaman dalam menjalankan tugasnya.

Organisasi perlu mencari sebab ketidakpuasan pegawai baik penyebab yang bersifat material maupun immaterial. Ketidakpuasan pegawai dapat dilakukan dengan berbagai cara, misalnya panjangnya masa kerja dalam organisasi menyebabkan pegawai berhenti, ketidakpatuhan terhadap perintah dan mengelak dari tanggung jawab kerja.

i. Pengaruh Gaya Kepemimpinan Terhadap Kepuasan Kerja

Kesimpulan dari teori PerilakuPerseorangan menurut Robbins (1996:6), bahwa hasil penelitian yang dilakukan di Universitas Negeri Ohio, Universitas Michigan, dan kisi manajerial menjelaskan bahwa pemimpin yang mempunyai gaya kepemimpinan berorientasi hubungan (consideration) mempunyai bawahan yang lebih terpuaskan dibandingkan dengan pemimpin yang mempunyai gaya kepemimpinan berorientasi tugas (initiating structure).

Dua dalil penting dari Teori Jalan-Tujuan menurut Gibson et al. (1997:302) yang menghubungkan antara gaya kepemimpinan dengan kepuasan, yaitu: 
1. Gaya kepemimpinan dapat diterima dan memuaskan sejauh bawahan menganggap gaya kepemimpinan tersebut merupakan sumber langsung dari kepuasan atau sebagai alat untuk mendapatkan kepuasan di waktu yang akan datang,

2. Gaya kepemimpinan dapat memotivasi bawahan sampai sejauh gaya kepemimpinan itu memuaskan kebutuhan bawahan yang digantungkan pada hasil karya yang efektif, dan gaya kepemimpinan tersebut melengkapi lingkungan bawahan dengan memberikan bimbingan, kejelasan pengarahan, dan imbalan yang perlu bagi hasil karya yang efektif.

Dari hasil studi lapangan yang terdapat dalam buku Gibson et al. (1997:268) bertujuan untuk mengetahui arah dari pengaruh kausal antara gaya kepemimpinan dengan kepuasan kerja karyawan mengatakan bahwa:

1. Perhatian pemimpin terhadap gaya kepemimpinannya menyebabkan kepuasan bawahan,

2. Hasil karya bawahan menyebabkan perubahan dalam tekanan pemimpin pada perhatian dan penyusunan hubungan gaya kepemimpinan dan hasil karya.

j. Kerangka Konseptual

Kerangka Konseptual Pengaruh Gaya Kepemimpinan Terhadap Kepuasan Kerja

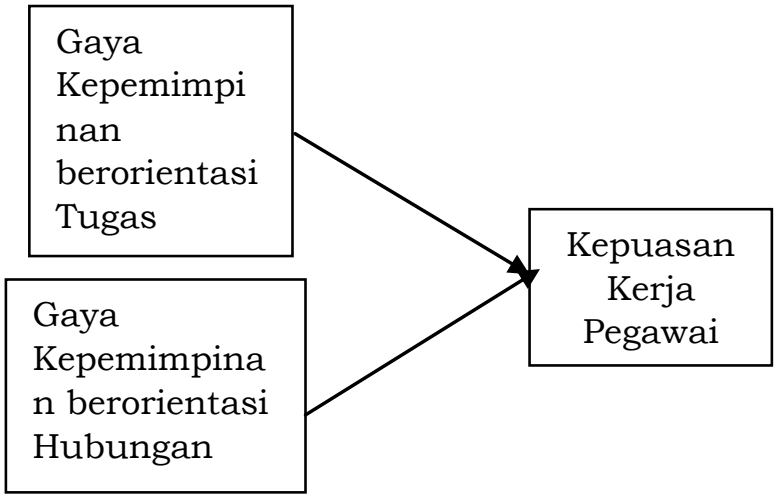

Berdasarkan perumusan masalah serta tujuan penelitian, maka hipotesis dalam penelitian ini adalah sebagai berikut:

1. diduga variabel bebas (X) gaya kepemimpinan berpengaruh signifikan terhadap kepuasan kerja pegawai (Y),

2. diduga variabel bebas $\left(\mathrm{X}_{1}\right)$ gaya kepemimpinan berorientasi tugas berpengaruh terbesar terhadap kepuasan kerja pegawai (Y).

\section{METODOLIGI PENELITIAN}

\section{a. Jenis dan Sumber Data}

Data pada penelitian ini merupakan jenis data kuantitatif yang berupa data hasil skoring kuesioner dari jawaban atas pertanyaan atau pernyataan dalam koesioner penelitian yang diberikan. Data-data tersebut bersumber dari dua jenis yaitu sebagai berikut :

1. Data Pimer, yaitu data yang diperoleh secara langsung dari sumbernya melalui proses wawancara dan dokumentasi pada pihak yang memiliki hubungan dengan masalah yang terkait dengan penelitian. Data primer ini meliputi data tentang 
pengaruh budaya perusahaan terhadap kinerja pegawai yang diperoleh melalui penyebaran kuesioner.

2. Data Sekunder, yaitu data yang diperoleh secara tidak langsung dari sumbernya, yang digunakan sebagai pelengkap data primer. Dalam penelitian ini sumber data sekunder diperoleh dari studi kepustakaan untuk mencari referensi buku yang digunakan sebagai acuan dengan tujuan memperoleh landasan ilmiah yang berbentuk teoritis. Data sekunder pada penelitian ini berupa gambaran umum perusahaan dan struktur organisasi yang diperoleh dari data inventaris.

\section{b. Populasi dan Sampel}

Populasi dalam penelitian ini menyangkut seluruh pegawai PT. Kereta Api Indonesia DAOP IX Jember. Pegawai PT. Kereta Api Indonesia DAOP IX Jember memiliki populasi kurang dari 100 sehingga sampel dalam penelitian ini adalah populasi pegawai PT. Kereta Api Indonesia DAOP IX Jember yang digunakan sebagai responden yang berjumlah 82 orang pegawai.

\section{c. Skala Pengukuran}

Skala pengukuran merupakan kesempatan yang digunakan sebagai acuan untuk menentukan panjang pendeknya interval dalam alat ukur. Alat ukur tersebut bila digunakan dalam pengukuran akan menghasilkan data kuantitatif. Skala dalam penelitian ini adalah Skala Likert. Skala likert digunakan untuk mengukur sikap, pendapat, dan persepsi orang atau sekelompok orang tentang fenomena sosial ini telah ditetapkan secara spesifik oleh peneliti, yang selanjutnya disebut sebagai variabel penelitian. Jawaban setiap item yang menggunakan skala likert mempunyai gradasi dari sangat positif sampai dengan sangat negatif.

\section{d. Metode Analisis Data}

\section{Uji Validitas}

Suatu skala pengukuran dikatakan valid apabila skala tersebut digunakan untuk mengukur apa yang seharusnya diukur (Sarwono, 2006:218). Oleh sebab itu, uji validitas dilakukan dengan tujuan untuk mengetahui sejauh mana validitas data yang diperoleh dari penyebaran kuisioner.

Dasar pengambilan keputusan dari uji validitas:

a. jika $r$ hasil positif dan $r_{\text {hasil }}>r_{\text {tabel }}$, maka variabel tersebut valid,

b. jika $\mathrm{r}$ hasil positif dan $\mathrm{r}_{\text {hasil }}<\mathrm{r}_{\text {tabel }}$, maka variabel tersebut tidak valid.

\section{Uji Reliabilitas}

Uji ini digunakan untuk menguji keandalan alat ukur dalam penelitian ini. Suatu alat ukur dikatakan reliabel jika alat pengukur tersebut dipakai dua kali untuk mengukur gejala yang sama akan memperoleh hasil pengukuran yang relatif konsisten.

Jadi, keputusan yang digunakan untuk menguji reliabilitas ini adalah: 
a. jika nilai $\alpha>0,20$, maka seluruh butir pertanyaan adalah reliabel. Dengan kata lain instrumen layak dan dapat digunakan.

b. Jika nilai $\alpha<0,20$, maka seluruh butir pertanyaan adalah tidak reliabel. Dengan kata lain instrumen tidak layak dan tidak dapat digunakan.

\section{Analisis Regresi Linier}

Berganda

Rumus ini digunakan untuk mengetahui besarnya pengaruh variabel bebas yaitu gaya kepemimpinan yang terdiri dari gaya kepemimpinan berorientasi tugas, gaya kepemimpinan berorientasi hubungan, dengan variabel terikat yaitu kepuasan kerja pegawai.

\section{Uji Heterokedastisitas}

Adanya heterokedastisitas berarti adanya varian variabel yang tidak sama (konstan). Untuk mendeteksi gejala heterokedastisitas, ada atau tidaknya pola yang terjadi pada nilai residu pada model. Pada kasus ini digunakan metode uji gleyser.

\section{Uji Multikolinieritas}

Multikolinieritas adalah suatu keadaan dimana satu atau lebih variabel bebas mempunyai korelasi atau hubungan dengan variabel bebas lainnya, dengan kata lain satu atau lebih variabel bebasnya merupakan fungsi linier dari variabel bebas yang lain. Untuk mengetahui ada tidaknya multikolinieritas dilakukan pengujian dengan melihat VIF atau Variance Inflation Factor dari masing-masing variabel bebas terhadap variabel terikatnya.

\section{Uji Autokorelasi}

Uji ini bertujuan untuk mengetahui apakah ada korelasi antara anggota serangkaian data observasi yang diuraikan menurut aktu (time series) atau ruang (cross section).

\section{Uji F}

Pengujian ini dilakukan untuk mengetahui pengaruh secara keseluruhan variabel bebas (X) terhadap variabel terikat (Y).

\section{Uji t}

Uji ini digunakan untuk mengetahui pengaruh variabel bebas terhadap variabel terikat secara parsial.

\section{PEMBAHASAN}

\section{Uji Validitas}

Tabel Rekapitulasi Hasil Uji

Validitas Variabel Gaya

Kepemimipinan Berorientasi Tugas

$\left(\mathrm{X}_{1}\right)$
\begin{tabular}{|l|c|c|c|c|}
\hline $\begin{array}{c}\text { Pertan } \\
\text { yaan }\end{array}$ & $\mathrm{r}_{\text {hitung }}$ & $\mathrm{r}_{\text {tabel }}$ & $\begin{array}{c}\text { Signifi } \\
\text { kansi }\end{array}$ & $\begin{array}{c}\text { Kete- } \\
\text { rangan }\end{array}$ \\
\hline 1 & 0,347 & 0,316 & 0,025 & Valid \\
2 & 0,555 & 0,316 & 0,000 & Valid \\
3 & 0,498 & 0,316 & 0,001 & Valid \\
4 & 0,598 & 0,316 & 0,000 & Valid \\
5 & 0,521 & 0,316 & 0,000 & Valid \\
6 & 0,620 & 0,316 & 0,000 & Valid \\
7 & 0,535 & 0,316 & 0,000 & Valid \\
8 & 0,634 & 0,316 & 0,000 & Valid \\
9 & 0,632 & 0,316 & 0,000 & Valid \\
\hline
\end{tabular}

Pada tabel rekaputilasi uji validitas menunjukkan bahwa $r_{\text {hitung }}$ yang dimiliki setiap item pertanyaan dalam variabel gaya kepemimpinan berorientasi tugas lebih besar dari 
$\mathrm{r}_{\text {tabel}}$. Dengan demikian, setiap pertanyaan yang digunakan dalam variabel gaya kepemimpinan berorientasi tugas ini dinyatakan valid sebagai alat instrumen pengumpulan data.

Hal ini juga dapat dilihat dari tingkat signifikansi $<0,05$. Sehingga dengan validitas data yang diperoleh, data dapat digunakan untuk analisis selanjutnya.

\begin{tabular}{lrr}
\multicolumn{2}{c}{ Tabel } & Rekapitulasi Hasil Uji \\
Validitas & Variabel & Gaya \\
Kepemimpinan & Berorientasi
\end{tabular}
Hubungan $\left(\mathrm{X}_{2}\right)$

\begin{tabular}{|l|c|c|c|c|}
\hline $\begin{array}{c}\text { Perta } \\
\text { nyaan }\end{array}$ & $\mathrm{r}_{\text {hitung }}$ & $\mathrm{r}_{\text {tabel }}$ & $\begin{array}{c}\text { Signif } \\
\text { ikansi }\end{array}$ & $\begin{array}{c}\text { Ketera } \\
\text { ngan }\end{array}$ \\
\hline 1 & 0,630 & 0,316 & 0,000 & Valid \\
2 & 0,623 & 0,316 & 0,000 & Valid \\
3 & 0,636 & 0,316 & 0,000 & Valid \\
4 & 0,424 & 0,316 & 0,005 & Valid \\
5 & 0,473 & 0,316 & 0,002 & Valid \\
6 & 0,567 & 0,316 & 0,000 & Valid \\
7 & 0,485 & 0,316 & 0,001 & Valid \\
8 & 0,378 & 0,316 & 0,015 & Valid \\
9 & 0,673 & 0,316 & 0,000 & Valid \\
\hline
\end{tabular}

Pada tabel rekapitulasi uji validitas menunjukkan bahwa $r_{\text {hitung }}$ yang dimiliki setiap item pertanyaan dalam variabel gaya kepemimpinan berorientasi hubungan lebih besar dari $r_{\text {tabel }}$. Dengan demikian, setiap item pertanyaan yang digunakan dalam variabel gaya kepemimpinan berorientasi hubungan ini dinyatakan valid sebagai alat instrumen pengumpulkan data.

Hal ini juga dapat dilihat dari tingkat signifikansi $<0,05$. Sehingga dengan validitas data yang diperoleh, data dapat digunakan untuk analisis selanjutnya.
Tabel Rekapitulasi Hasil Uji Validitas Variabel Kepuasan Kerja (Y)

\begin{tabular}{|c|c|c|c|c|}
\hline $\begin{array}{c}\text { Perta } \\
\text { nyaan }\end{array}$ & $\mathrm{r}_{\text {hitung }}$ & $\mathrm{r}_{\text {tabel }}$ & $\begin{array}{c}\text { Signi- } \\
\text { fikansi }\end{array}$ & $\begin{array}{c}\text { Kete- } \\
\text { rangan }\end{array}$ \\
\hline 1 & 0,493 & 0,316 & 0,001 & Valid \\
2 & 0,794 & 0,316 & 0,000 & Valid \\
3 & 0,813 & 0,316 & 0,000 & Valid \\
4 & 0,806 & 0,316 & 0,000 & Valid \\
5 & 0,484 & 0,316 & 0,001 & Valid \\
\hline \multicolumn{5}{|c}{ Pada tabel rekapitulasi uji }
\end{tabular}

validitas menunjukkan bahwa $r_{\text {hitung }}$ yang dimiliki setiap item pertanyaan dalam variabel kepuasan kerja lebih besar dari $r_{\text {tabel. }}$. Dengan demikian, setiap item pertanyaan yang digunakan dalam variabel kepuasan kerja ini dinyatakan valid sebagai alat instrumen pengumpulkan data.

Hal ini juga dapat dilihat dari tingkat signifikansi $<0,05$. Sehingga dengan validitas data yang diperoleh, data dapat digunakan untuk analisis selanjutnya.

\section{Uji Reliabilitas}

Uji reliabilitas ini dilakukan untuk menguji keandalan alat ukur yang digunakan. Pengujian reliabilitas dalam penelitian ini menggunakan rumus model alpha (a) dengan menggunakan bantuan program SPSS versi 12.0, kemudian dibandingkan dengan angka kritis reliabilitas sebesar 0,20. Jika nilai alpha $(\alpha)$ lebih besar dari 0,20 maka seluruh pertanyaan dalam setiap variabel dapat dikatakan reliabel atau layak untuk digunakan. 
Tabel Rekapitulasi Hasil Uji Reliabilitas

\begin{tabular}{|c|c|c|c|}
\hline Variabel & $\begin{array}{c}\text { Alpha } \\
(\alpha)\end{array}$ & $\begin{array}{c}\text { Angka } \\
\text { kritis }\end{array}$ & Keterangan \\
\hline $\mathrm{X}_{1}$ & 0,7090 & 0,20 & Reliabel \\
$\mathrm{X}_{2}$ & 0,6784 & 0,20 & Reliabel \\
$\mathrm{Y}$ & 0,7260 & 0,20 & Reliabel \\
\hline \multicolumn{3}{|c}{ tabel rekapitulasi uji }
\end{tabular}

Pada tabel rekapitulasi uji reliabilitas dapat disimpulkan bahwa seluruh variabel bebas yang digunakan dalam penelitian ini, yang terdiri dari variabel gaya kepemimpinan berorientasi tugas, gaya kepemimpinan berorientasi hubungan dan kepuasan kerja adalah reliabel, karena dari hasil pengujian diperoleh koefisien cronbach alpha $(\alpha)$ lebih besar dari 0,20.

\section{Analisis Regresi Linier Berganda}

Tabel Hasil Analisis Regresi

Linier Berganda

\begin{tabular}{|c|c|c|}
\hline $\begin{array}{c}\text { Variabe } \\
\text { Bebas }\end{array}$ & $\begin{array}{c}\text { Variabel } \\
\text { Terikat }\end{array}$ & $\begin{array}{c}\text { Koefisien } \\
\text { Regresi }\end{array}$ \\
\hline \multirow{3}{*}{$\mathrm{Y}$} & Konstanta & \\
& $(\mathrm{a})$ & 1,46 \\
& $\mathrm{X}_{1}$ & 0,574 \\
& $\mathrm{X}_{2}$ & 0,368 \\
\hline
\end{tabular}

Pada tabel menunjukkan persamaan regresi linier berganda sebagai berikut:

$\mathrm{Y}=1,46+0,574 \mathrm{X}_{1}+0,368 \mathrm{X}_{2}+\mathrm{ei}$ Analisis dari persamaan tersebut adalah:

a. Konstanta (a) = 1,46 dan bertanda positif mempunyai arti apabila variabel gaya kepemimpinan berorientasi tugas dan gaya kepemimpinan berorientasi hubungan tidak mengalami peningkatan ataupun penurunan (sama dengan nol) maka kepuasan kerja akan mengalami peningkatan. Hal ini dikarenakan konstanta bertanda positif.

b. Koefisien regresi variabel gaya kepemimpinan berorientasi tugas adalah sebesar 0,574. Koefisien regresi tersebut bertanda positif yang menunjukkan bahwa antara variabel gaya kepemimpinan berorientasi tugas dengan kepuasan kerja terdapat hubungan yang searah, artinya jika ada peningkatan gaya kepemimpinan berorientasi tugas maka kepuasan kerja juga akan meningkat.

c. Koefisien regresi variabel gaya kepemimpinan berorientasi hubungan adalah sebesar 0,368. Koefisien regresi tersebut bertanda positif yang menunjukkan bahwa antara variabel gaya kepemimpinan berorientasi hubungan dengan kepuasan kerja terdapat hubungan yang searah, artinya jika ada peningkatan gaya kepemimpinan berorientasi hubungan maka kepuasan kerja juga akan meningkat.

\section{Uji Heterokedastisitas}

Tabel Rekapitulasi Hasil Uji Heterokedastisitas (Gleyser)

\begin{tabular}{|c|c|c|c|}
\hline Variabel & $\mathrm{t}_{\text {hitung }}$ & $\mathrm{t}_{\text {tabel }}$ & $\mathrm{sig}$ \\
\hline $\mathrm{X}_{1}$ & 1,864 & 2,024 & 0,070 \\
$\mathrm{X}_{2}$ & $-1,007$ & 2,024 & 0,320 \\
\hline
\end{tabular}

Pada tabel menunjukkan hasil regresi residual seluruh variabel bebas mempunyai $t_{\text {hitung }}<t_{\text {tabel }}$, 
sedangkan nilai $t_{\text {tabel }}$ pada baris degree of freedom $(d f)=\mathrm{n}-\mathrm{k}-1$ (41-21=38) dan alpha $(\alpha)$ 5\% diperoleh nilai $t_{\text {tabel }}$ sebesar 2,024 dan variabel penelitian ini mempunyai tingkat signifikansi > 0,05, maka dalam penelitian ini tidak terjadi gejala heterokedastisitas.

\section{Uji Multikolinieritas}

Tabel Nilai VIF dan Tolerance

\begin{tabular}{|c|c|c|}
\hline Variabel & Nilai VIF & $\begin{array}{c}\text { Nilai } \\
\text { Tolerance }\end{array}$ \\
\hline $\mathrm{X}_{1}$ & 1,981 & 0,505 \\
$\mathrm{X}_{2}$ & 1,981 & 0,505 \\
\hline
\end{tabular}

Pada tabel dapat dilihat bahwa variabel gaya kepemimpinan berorientasi tugas, dan gaya kepemimpinan berorientasi hubungan mempunyai nilai $V I F<10$ dan Tolerance $>0,10$ atau $<10$, sehingga dapat disimpulkan bahwa model dalam penelitian ini untuk semua variabel bebasnya tidak mengalami multikolinieritas.

\section{Uji Autokorelasi}

Tabel Nilai Uji $D-W$

\begin{tabular}{|c|c|c|c|}
\hline No & Variabel & Sig & Nilai \\
& & & $D-W$ \\
\hline 1 & $\mathrm{X}_{1}$ & & \\
2 & $\mathrm{X}_{2}$ & 0,000 & 1,941 \\
3 & $\mathrm{Y}$ & & \\
\hline \multicolumn{3}{|c|}{ Pada tabel dapat diketahui }
\end{tabular}

bahwa hasil output SPSS menunjukkan angka Durbin-Watson Test sebesar 1,941. Angka kritis dU pada taraf signifikansi 5\%, k (jumlah variabel) $=2$ dan n (jumlah sampel) $=41$ adalah 1,60. Maka kriteria pengujiannya adalah dU < DW < (4$\mathrm{dU})=1,60<1,941<2,4$.

\section{Uji F}

Tabel Hasil Analisis Uji F

Pada tabel dapat diketahui bahwa $\mathrm{F}_{\text {hitung }}>\mathrm{F}_{\text {tabel}}$, sehingga Ho ditolak dan Ha diterima. Sehingga semua variabel bebas (independen), yaitu gaya kepemimpinan

\begin{tabular}{|l|l|c|c|}
\hline $\begin{array}{l}\text { Variabel } \\
\text { Terikat }\end{array}$ & \multicolumn{1}{|c|}{$\begin{array}{c}\text { Variabel } \\
\text { Bebas }\end{array}$} & $F_{\text {hitung }}$ & $F_{\text {tabel }}$ \\
\hline & $\begin{array}{l}\text { Gaya } \\
\text { kepemimpinan } \\
\text { Berorientasi } \\
\text { Tugas }\left(\mathrm{X}_{1}\right) \text { dan } \\
\text { Kepuasan } \\
\text { Kerja (Y) } \\
\text { Kepemimpinan } \\
\text { Berorientasi } \\
\text { Hubungan }\left(\mathrm{X}_{2}\right)\end{array}$ & 60,789 & 3,24 \\
\\
berorientasi tugas \\
kepemimpinan
\end{tabular}

hubungan secara simultan (bersamasama) memiliki pengaruh nyata terhadap variabel terikat (dependen), yaitu kepuasan kerja pegawai PT. Kereta Api Indonesia DAOP IX Jember.

\section{Analisis Koefisien determinasi Berganda $\left(\mathbf{R}^{2}\right)$}

Tabel Hasil Pengujian Koefisien Determinasi Berganda

\begin{tabular}{|c|c|c|}
\hline $\begin{array}{c}\text { Variabel } \\
\text { Bebas }\end{array}$ & $\begin{array}{c}\text { Nilai } R \\
\text { Square }\end{array}$ & $\begin{array}{c}\text { Persentase } \\
(\%)\end{array}$ \\
\hline $\mathrm{X} 1, \mathrm{X}_{2}$ & 0,762 & $76,20 \%$ \\
\hline \multicolumn{2}{|c|}{ Pada tabel dapat diketahui }
\end{tabular}

bahwa perhitungan dengan program SPSS versi 12.0 diperoleh nilai koefisien determinasi berganda $(R$ Square) sebesar 0,762 artinya kepuasan kerja pegawai PT. Kereta Api Indonesia DAOP IX Jember dipengaruhi oleh variabel gaya kepemimpinan beerorientasi tugas dan gaya kepemimpinan berorientasi hubungan secara bersama-sama 
sebesar $76,2 \%$, sedangkan $23,8 \%$ dipengaruhi oleh variabel-variabel lain di luar variabel-variabel dalam penelitian ini.

\section{Uji t}

Tabel Hasil Analisis Uji t

\begin{tabular}{|c|c|c|c|}
\hline Variabel & $\mathrm{t}_{\text {hitung }}$ & $\mathrm{t}_{\text {tabel }}$ & $\mathrm{Sig}$ \\
\hline $\mathrm{X}_{1}$ & 5,155 & 1,68 & 0,000 \\
$\mathrm{X}_{2}$ & 3,299 & 1,68 & 0,002 \\
\hline
\end{tabular}

Pada tabel hasil analisis Uji $\mathrm{t}$ dapat diketahui bahwa seluruh variabel bebas berpengaruh nyata dan signifikan secara individu atau parsial terhadap kepuasan pegawai PT. Kereta Api Indonesia DAOP IX Jember. Masing-masing variabel dapat dijelaskan sebagai berikut:

a. $\mathrm{X} 1=$ diketahui $t_{\text {hitung }}$ untuk variabel gaya kepemimpinan berorientasi tugas lebih besar dari $t_{\text {tabel }}$ yaitu $5,155>1,68$ yang berarti Ho ditolak. Hal ini menunjukkan bahwa variabel gaya kepemimpinan berorientasi tugas berpengaruh signifikan terhadap kepuasan kerja pegawai PT. Kereta Api Indonesia DAOP IX Jember.

b. $\mathrm{X} 2=$ diketahui $\mathrm{t}_{\text {hitung }}$ untuk variabel gaya kepemimpinan berorientasi hubungan lebih besar dari $t_{\text {tabel }}$ yaitu 3,299 > 1,68 yang berarti Ho ditolak. Hal ini menunjukkan bahwa variabel gaya kepemimpinan berorientasi hubungan berpengaruh signifikan terhadap kepuasan kerja pegawai PT. Kereta Api Indonesia DAOP IX Jember.
Koefisien Determinasi Parsial ( $\mathbf{r}^{2}$ )

Tabel Hasil Analisis Koefisien Determinasi Parsial

\begin{tabular}{|c|c|c|}
\hline No & Variabel & $\mathrm{r}^{2}$ \\
\hline 1 & $\mathrm{X}_{1}$ & 0,641 \\
2 & $\mathrm{X}_{2}$ & 0,472 \\
\hline \multicolumn{2}{|c|}{ Pada tabel } & koefisien
\end{tabular}

determinasi parsial dapat diketahui bahwa besarnya koefisien korelasi parsial untuk variabel gaya kepemimpinan berorientasi tugas adalah 0,641 atau sebesar $64,1 \%$ dan gaya kepemimpinan berorientasi hubungan adalah 0,472 atau sebesar $47,2 \%$. Berdasarkan hasil tersebut, dapat disimpulkan dari kedua variabel yang memiliki pengaruh paling besar terhadap kepuasan kerja pegawai PT. Kereta Api Indonesia DAOP IX Jember adalah variabel gaya kepemimpinan berorientasi tugas.

\section{PENUTUP}

\section{a. Kesimpulan}

Berdasarkan hasil penelitian pengaruh gaya kepemimpinan terhadap kepuasan kerja pegawai PT. Kereta Api Indonesia DAOP IX Jember, maka dapat disimpulkan sebagai berikut:

1. Hasil analisis regresi linier berganda menunjukkan bahwa variabel gaya kepemimpinan berpengaruh terhadap kepuasan kerja pegawai PT. Kereta Api Indonesia DAOP IX Jember. Pengaruh secara simultan dapat dilihat dari hasil analisis uji $\mathrm{F}$ yang dilakukan yaitu 
menghasilkan nilai $F_{\text {hitung }}$ lebih besar dari nilai $\mathrm{F}_{\text {tabel }}(60,789>$ $3,24)$ artinya bahwa variabel gaya kepemimpinan ini secara simultan mempunyai pengaruh yang signifikan terhadap kepuasan kerja pegawai PT. Kereta Api Indonesia DAOP IX Jember. Sedangkan dari hasil analisis koefisien determinasi berganda $\left(\mathrm{R}^{2}\right)$ diperoleh nilai $R$ Square sebesar 0,762. Hal ini berarti bahwa gaya kepemimpinan berpengaruh secara nyata dan signifikan terhadap kepuasan kerja pegawai PT. Kereta Api Indonesia DAOP IX Jember sebesar 76,2\%, sedangkan sisanya sebesar $23,8 \%$ disebabkan faktor-faktor lain di luar penelitian ini.

2. Sementara itu, hasil analisis uji $\mathrm{t}$ menunjukkan bahwa untuk variabel gaya kepemimpinan berorientasi tugas memiliki nilai $t_{\text {hitung }}$ lebih besar dari $t_{\text {tabel }}(5,155$ $>1,68)$. Untuk variabel gaya kepemimpinan berorientasi hubungan memiliki nilai $t_{\text {hitung }}$ lebih besar dari $t_{\text {tabel }}(3,299>$ 1,68). Hal ini berarti bahwa kedua variabel gaya kepemimpinan tersebut secara parsial berpengaruh nyata dan signifikan terhadap kepuasan kerja pegawai PT. Kereta Api Indonesia DAOP IX Jember. Berdasarkan analisis koefisien determinasi parsial $\left(\mathrm{r}^{2}\right)$ untuk aspek gaya kepemimpinan yang berpengaruh terbesar terhadap kepuasan kerja pegawai PT. Kereta Api Indonesia DAOP IX Jember adalah variabel gaya kepemimpinan berorientasi tugas dengan kontribusi sebesar $64,1 \%$.

\section{b. Saran}

Berdasarkan kesimpulan penelitian pengaruh gaya kepemimpinan terhadap kepuasan kerja pegawai PT. Kereta Api Indonesia DAOP IX Jember disarankan:

1. Dalam usaha meningkatkan kepuasan kerja pegawai, salah satu caranya adalah dengan cara menerapkan gaya kepemimpinan yang tepat dan sesuai. Pihak pimpinan setidaknya harus memperhatikan kedua aspek gaya kepemimpinan. Hasil analisis penelitian menunjukkan bahwa kedua variabel gaya kepemimpinan tersebut memiliki pengaruh yang nyata terhadap kepuasan kerja pegawai PT. Kereta Api Indonesia DAOP IX Jember. Dari hasil penelitian diketahui bahwa variabel gaya kepemimpinan berorientasi tugas mempunyai pengaruh yang terbesar terhadap kepuasan kerja pegawai PT. Kereta Api Indonesia DAOP IX Jember. Sehingga dapat diketahui bahwa variabel gaya kepemimpinan berorientasi tugas yang diterapkan oleh pimpinan PT. Kereta Api Indonesia DAOP IX 
Jember sangat berpengaruh terhadap kepuasan kerja pegawai. Sehingga melihat hal tersebut seharusnya pihak manajemen perusahaan sebaiknya lebih menitikberatkan kepada faktor gaya kepemimpinan berorientasi tugas supaya terjamin terlaksananya tugas dengan baik dan tercapainya kepuasan kerja pegawai.

2. Dari pihak pimpinan sendiri, agar selalu intens dalam memperhatikan kepuasan kerja pegawainya. Apabila tingkat neglect, eksit, voice semakin meningkat, dan loyalty dirasa telah menurun, maka pihak pimpinan harus mengambil kebijakan sehingga kepuasan kerja pegawai bisa tetap tumbuh dan terjaga. Pimpinan PT. Kereta Api Indonesia DAOP IX Jember juga perlu mengkaji lebih lanjut mengenai faktorfaktor yang dapat meningkatkan kepuasan kerja selain dari variabel gaya kepemimpinan berorientasi tugas dan gaya kepemimpinan berorientasi hubungan karena variabel gaya kepemimpinan ini hanya memberi kontribusi sebesar $76,2 \%$. Hal ini menunjukkan bahwa masih terdapat faktorfaktor lain di luar penelitian ini yang mempengaruhi kepuasan kerja pegawai yaitu sebesar $23,8 \%$. Sedangkan gaya kepemimpinan berorientasi tugas mempunyai pengaruh terbesar yang memberi kontribusi sebesar $64,1 \%$.

\section{DAFTAR PUSTAKA}

Arikunto. 1992. Prosedur Penelitian Suatu Praktik. Jakarta: Rineka Cipta.

Arisapna, Tiasa Nugraha. 2004. Analisis Faktor-Faktor Yang Mempengaruhi Kepuasan Kerja Karyawan pada PT TASPEN (Persero) Cabang Jember. Skripsi. Jember: Universitas Jember.

Gibson, Ivancevich dan Donelly. 1997. Organisasi dan Manajemen. Edisi Keempat. (Terjemahan: Djoerban Wahid). Jakarta: Penerbit Erlangga.

Gibson, Ivancevich dan Donelly. 1996. Organisasi. Edisi Kelima. Jilid I. (Terjemahan: Djarkasih). Jakarta: Penerbit Erlangga.

Handoko, T. Hani. 2000. Manajemen Personalia Dan Sumber Daya Manusia. Edisi 2. Yogyakarta: BPFE.

Hersey, Paul dan Blanchard, Ken. 1995. Manajemen Perilaku Organisasi: Pendayagunaan SDM. Edisi Keempat. (Terjemahan: Agus Dharma). Jakarta: Penerbit Erlangga.

Manullang. 1994. Manajemen

Sumber Daya Manusia.

Jakarta: Ghalia Indonesia. 
Moestopo, Arief. 2001. Hubungan

Gaya Kepemimpinan dengan Disiplin Kerja Karyawan pada PT Saritama Pratama Ponorogo. Skripsi. Jember: Universitas Jember.

Nawawi, Hadari. 2000. Manajemen Sumber Daya Manusia Untuk Bisnis yang Kompetitif. Yogyakarta: Gajah Mada University Press.

Robbins, Stephen P. 1996. Perilaku Organisasi: Konsep,

Kontroversi, Apilkasi. (Terjemahan: Hadyana Pujaatmaka). Jakarta: PT Prenhallindo.

Robbins, Stephen P. 2002. Prinsipprinsip perilaku organisasi. Jakarta: Erlangga.

Rois, Amirullah dan Siti. 2003. Perilaku Organisasi. Malang. Bayumedia.

Siagian, Sondang P. 2003. Organisasi, Kepemimpinan dan Perilaku Organisasi. Jakarta: Gunung Agung.

Singarimbun dan Effendi. 1995. Metode Penelitian Survei. Jakarta: LP3ES.

Siswanto, Bedjo. 1990. Manajemen Modern. (Konsep dan Aplikasi). Penerbit Sinar Baru.

Stoner, James A.F. dan Freeman, R. Edward. 1994. Manajemen.
Edisi Kelima. Jilid II. (Terjemahan: Wilhelmus W. Bakowatun dan Benyamin Molan). Jakarta: Intermedia. Stoner, James A.F. dan Freeman, R. Edward. 1992. Manajemen. Edisi Kedua. Jilid II. (Terjemahan: Agus Maulana, Hendardi, dan Khristina). Jakarta: Penerbit Erlangga.

Sugiyono. 2006. Metode Penelitian Administrasi. Bandung: Alfabeta.

Sugiyono. 2008. Metode Penelitian Administrasi. Bandung: Alfabeta.

Thoha, Miftah. 2003. Prilaku Organisasi: Konsep Dasar dan Aplikasinya. Jakarta: PT. Rajagrafindo Persada.

Umar, Husein. 2000. Metode Penelitian Untuk Tesis dan Bisnis. Jakarta: Raja Grapindo Persada.

Winardi. 1996. Organisasi dan Motivasi. Bandung: Alumni.

Yukl, Gary. 1998. Kepemimpinan Dalam Organisasi. (Terjemahan: Jusuf Udaya). Jakarta: PT Prenhallindo.

www.keretaapi.co.id 